\title{
Investigation of Bioactive Compounds on Relict Endemic Ajuga relicta P. H. Davis (Lamiaceae) from Turkey
}

\author{
Nazan Comlekcioglu (1),*, Yusuf Ziya Kocabas (i)2, Ashabil Aygan (1) \\ ${ }^{1}$ Kahramanmaras Sutcu Imam University, Faculty of Science and Letters, Department of Biology, \\ Kahramanmaras, Turkey \\ ${ }^{2}$ Kahramanmaras Sutcu Imam University, Turkoglu Vocational High School, Medicinal Plants Department, \\ Kahramanmaras, Turkey
}

\begin{abstract}
Species belonging to genus Ajuga (Lamiaceae) have been used to treat many diseases in traditional medicine. The plants of the genus Ajuga have been reported to have antifungal, antibacterial, antimycobacterial, antihypertensi ve, antiplasmodial, hypoglycaemic, and larvae and insect activity. Ajuga relicta is a relict endemic plant which grows only in Kahramanmaras. The total phenolic contents of the extracts have been quantified with Folin Ciocalteu colorimetric method, and the antioxidant activities of the extracts have been tested with DPPH, and FRAP. Antimicrobial activities of plant extracts were determined by the welldiffusion method against seven bacteria and four yeasts. Besides, the fatty acid composition was determined in GC-MS. As a result of GC-MS analysis of the oil obtained from the $A$. relicta extracts, 21 different fatty acids were identified. The highest contents of these fatty acids were palmitic acid $(29.50 \%)$, oleic acid $(23.51 \%)$, stearic acid $(9.13 \%)$ and linoleic acid $(7.18 \%)$. Total phenolic value of plant extract was $11.94 \mathrm{mg} / \mathrm{g}$, total flavonoid amount $2.28 \mathrm{mg} / \mathrm{g}$, FRAP value $43.53 \mathrm{~g} / \mathrm{g}$ and DPPH value $1.63 \mathrm{mg} / \mathrm{g}$. Antimicrobial activity experiment on a total of 11 microorganisms (seven bacteria and four yeast) showed that Ajuga extracts inhibited the growth of tested microorganisms except Enterobacter cloacae, Candida glabrata and Saccharomyces cerevisiae. A. relicta was found to have high bioactive content and antimicrobial activity. The plant extracts are rich in constant fatty acids and similar to olive oil (palmitic-oleic-linoleic), which is well known for its health benefits in terms of major fatty acids.
\end{abstract}

\section{ARTICLE HISTORY}

Received: January 04, 2019

Revised: June 13, 2019

Accepted: July 29, 2019

\section{KEYWORDS}

Ajuga relicta,

Antimicrobial,

Bioactive compounds,

Fatty acid,

Relict-endemic

\section{INTRODUCTION}

Plants are generally unique sources of new drugs that play an important role in the treatment of human diseases. Infectious diseases are one of the most important problems the communities face all over the world. Because of the adverse side effects of synthetic drugs and the emergence of antibiotic-resistant bacteria, new natural compounds with broad activity against bacterial strains are required. Plant secondary metabolites are excellent candidates for developing new phytopharmaceuticals with various biological activities. However, herbal

\footnotetext{
${ }^{*}$ CONTACT: Nazan Comlekcioglu $\square$ noktem80@gmail.com $\equiv$ Kahramanmaras Sutcu Imam University, Faculty of Science and Letters, Department of Biology, Kahramanmaras, Turkey
} 
medicines have not been scientifically researched enough. It is often applied on the basis of knowledge and experimental observations of traditional healers [1]. In this context, new investigations on medicinal plants or herbal products, which traditionally used but not scientifically researched, will greatly, contribute to the development of new herbal medicines or herbal formulations [2].

Species belonging to Lamiaceae family are known for their biological activities and especially their antioxidative properties. Lamiaceae is represented by 236 genera and 7200 species worldwide [3]. Lamiaceae is the third largest plant family in Turkey, 46 genera and 580 species are represented. Of these species, 260 are endemic and the endemism rate is approximately $45 \%[4,5]$. The Ajuga genus, a member of the Lamiaceae family, has more than 300 species of annual and perennial herbaceous flowering plants distributed in the temperate regions of Asia, Europe, Australia, North America and Africa [6]. Ajuga has 13 species (6 endemic) and 10 subtypes (1 endemic) in Turkey [4].

Several species of the genus Ajuga (Lamiaceae) are used in African and Asian folk medicine. These plants are used as folk remedies in the world for effective antihelminthic, tightening, antifungal, and anti-inflammatory agents as well as rheumatism, fever, toothache, dysentery, malaria, hypertension, diabetes and gastrointestinal disorders [7]. In addition to these features, this plant is used against eczema, tonic, menstrual diuretic, wounds and as an antidote against the bites of venomous animals in Turkey [8]. This study was done with A. relicta, which is known very little about it. The plant was first collected in 1907 from Kahramanmaraş Ahırdağı. But the plant is no longer seen in Ahırdağı. It is estimated that A. relicta has disappeared as a result of the elimination of moist habitats around $1830 \mathrm{~m}$ and heavy grazing [9]. A. relicta, an herbaceous perennial plant, is an endemic species. It is a plant belonging to the old glacial period and it is only grown in the world in Kahramanmaraş, Çimendağı/Yavşan Plateau. Recently, the demand for Ajuga species, which is considered to be an ornamental plant, has increased significantly in addition to its medical and pharmacological properties. Although the genus Ajuga has been widely studied, there is very little literature about A. relicta. There is no study about $A$. relicta in the literature other than systematic, steroids and terpenoids, morphoanatomical study and antioxidant activity [5, 10-12].

The aim of this study was to investigate the antioxidant and antimicrobial activities, total phenol and flavonoid content of aerial parts of endemic A. relicta, whose taxa are in restricted areas and exhausted over the years. Fatty acid content of plant extracts was also investigated by using GC-MS. Although the antioxidant activity and total phenolic content of A. relicta has been previously investigated, but total flavonoid content, antimicrobial activity, fatty acid content has been investigated for the first time.

\section{MATERIAL and METHODS}

\subsection{Plant materials}

The plants used in this study were collected from openings in the forested areas of Çimendağı-Yavşan Plateau at an altitude of approximately 1500 m, on 20 July 2015 (Figure 1). Plants were identified according to Flora of Turkey [4]. A voucher specimen was deposited in the Herbarium of the KSU [YZK-980].

\subsection{Sample Preparation and Extraction}

The plants have been dried for a week (in a room temperature) and then powdered by grinding in a Waring blender. The extraction was performed by using Soxhelet apparatus at 60 ${ }^{\circ} \mathrm{C}$ for 6 hours with the addition of methanol $(100 \mathrm{ml})$ on to $10 \mathrm{~g}$ of the plant material. After elimination of the solvent in a vacuum rotary evaporator at $40{ }^{\circ} \mathrm{C}$, the extract was stored at -20 ${ }^{\circ} \mathrm{C}$ for further analysis [13]. Total phenolics, total flavonoids, antioxidant activity and 
antimicrobial activity were analyzed using these obtained extracts. Total phenolics, total flavonoids, antioxidant activity and antimicrobial activity were also analyzed on this extracts.
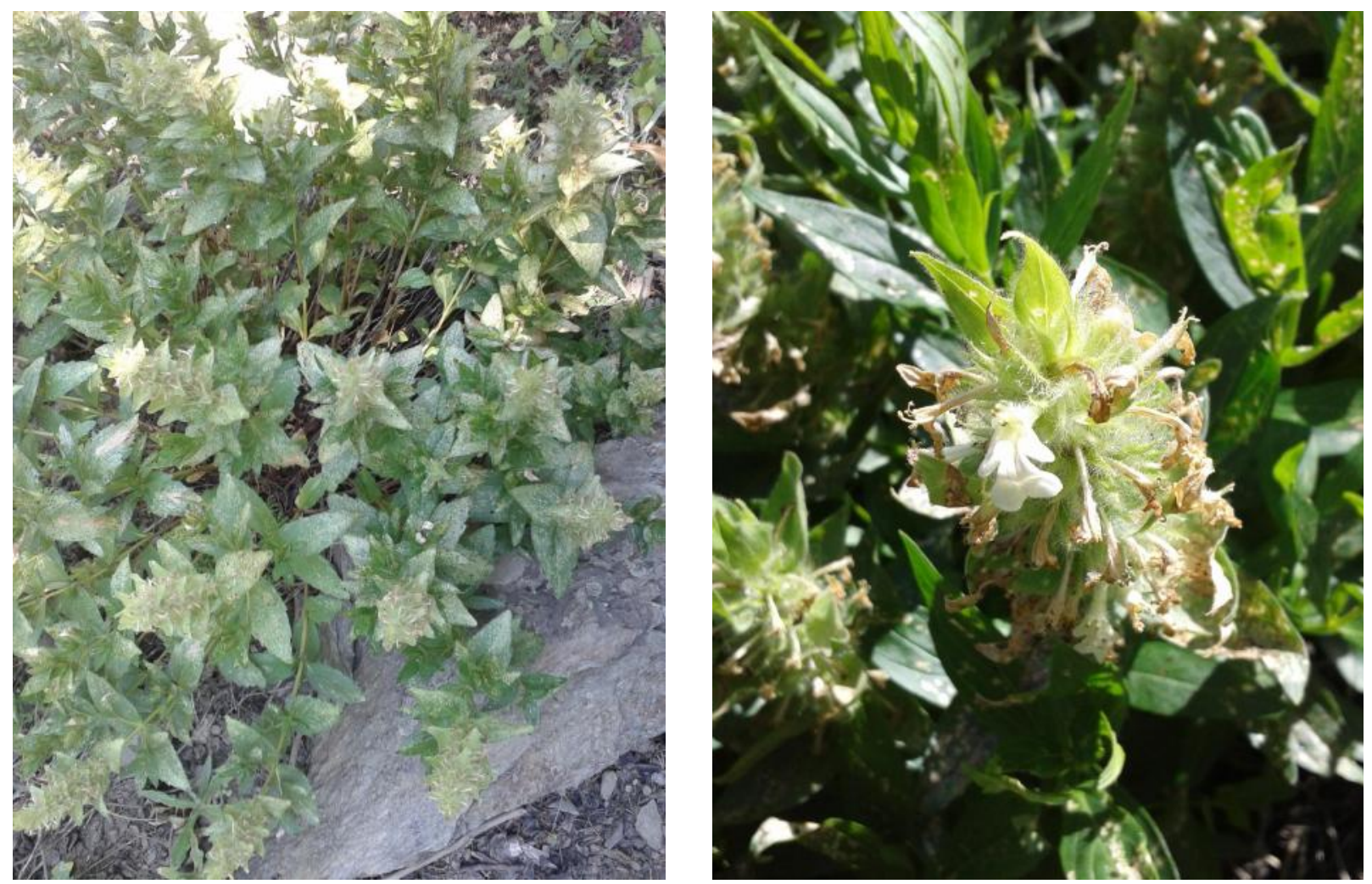

Fig 1. Appearance of A. relicta in nature (a), flower (b).

\subsection{Determination of ash and protein content}

The ash content was analyzed according to the European standard method UNIEN 14775 [14]. Protein content of the samples was assayed by using AOAC method [15]. All experiments were done in triplicate.

\subsection{Antioxidant Assay}

\subsubsection{Determination of Total Phenolic and Flavonoid Content}

Total phenolic contents of the fractions were determined using the Folin-Ciocalteau colorimetric method [16]. The total flavonoid content in leaf extracts was determined spectrophotometrically [17]. All experiments were performed in triplicate.

\subsubsection{DPPH and FRAP Analysis}

Scavenging free radical potentials were analyzed using 1,1-Diphenyl-2-picryl-hydrazyl (DPPH) [18]. Ascorbic acid was used as positive control. The results were indicated as IC50 value which is the concentration of sample required to scavenge 50\% of DPPH free radicals. The FRAP assay was carried out according to Benzie and Strain [19]. All experiments were done in triplicate.

\subsection{Antimicrobial Assay}

The antimicrobial activities were researched using the well-diffusion method. The test microorganisms were Enterobacter cloacae ATCC 13047D, Escherichia coli ATCC 39628, Klebsiella pneumonia, Bacillus subtilis ATCC 6633, Enterococcus faecalis ATCC 29212, Staphylococcus aureus ATCC 6538P, Sarcina lutea ATCC 9341NA, Candida albicans, 
Candida parapsilosis, Candida glabrata and Saccharomyces cerevisiae. Mueller Hinton agar plates were cultured with standardized inoculums $\left(10^{8} \mathrm{cfu} / \mathrm{ml}\right)$ of each bacterial strain and also Sabouraud dextrose agar were cultured with each of yeast strains $\left(2.1 \times 10^{3} \mathrm{cfu} / \mathrm{ml}\right)$ [20]. Extracts $(50 \mu \mathrm{l})$ were added into wells and the plates were incubated at $37^{\circ} \mathrm{C}$ for $16-18 \mathrm{~h}$. After incubation, the diameter of inhibition zones was measured by a compass. DMSO was used as solvent control since it was used as a solvent for extraction. The plant extracts showing antimicrobial activity were then tested to determine the MIC values in a microwell plate [20].

\subsection{Determination of Fatty Acid Content}

Total $0.1 \mathrm{~g}$ of plant extract was mixed with $1 \mathrm{ml}$ of $\mathrm{KOH}$ solution prepared with $2 \mathrm{~N}$ methanol and then vortexed for $2 \mathrm{~min}$. After 15 minutes, $10 \mathrm{ml}$ of hexane was added and the mixture was stirred well. After centrifugation at $7000 \mathrm{rpm}$ for $10 \mathrm{~min}, 1$ microliter of the upper phase was injected into the GC-MS device [21]. GC-MS analyses were quantified using a Shimadzu 2025 gas chromatograph (Shimadzu, Kyoto, Japan) equipped with a Shimadzu AOC20i automatic sampler (Shimadzu, Kyoto, Japan). The condition of GC analysis was as follows: flame ionization detector (FID) $250{ }^{\circ} \mathrm{C}$; column TR-CN100, $60 \mathrm{~m} \times 0.25 \mathrm{~mm} \times 0.20 \mathrm{~mm}$ (Teknokroma); carrier gas He with a flow rate of $1.5 \mathrm{~mL} / \mathrm{min}$. Fatty acid peaks were identified against the chromatogram of a mixed fatty acid methyl ester standard (37 Comp. FAME Mix $10 \mathrm{mg} / \mathrm{mL}$ in $\mathrm{CH}_{2} \mathrm{Cl}_{2}$; Supelco, USA). The injector and detector temperatures were kept at 250 ${ }^{\circ} \mathrm{C}$. The column oven temperature was programmed at $80{ }^{\circ} \mathrm{C}$ for $2 \mathrm{~min}$ initially, then $5^{\circ} \mathrm{C} / \mathrm{min}$ up to $140{ }^{\circ} \mathrm{C}$ (maintained for $2 \mathrm{~min}$ at $140{ }^{\circ} \mathrm{C}$ ), and then $3{ }^{\circ} \mathrm{C} / \mathrm{min}$ up to $240{ }^{\circ} \mathrm{C}$ (maintained for $5 \mathrm{~min}$ at $240{ }^{\circ} \mathrm{C}$ ). The injection and detector temperatures were set at 240 and $250{ }^{\circ} \mathrm{C}$, respectively. The fatty acids were expressed as percentage of the total fatty acids, calculated with peak areas.

\section{RESULT and DISCUSSION}

\subsection{Protein, ash, fatty oil content and fatty acid composition of $A$. relicta}

The results of protein, ash and oil content in leaves of A. relicta ranged to $6.36 \%, 8.64 \%$ and $4.53 \%$, respectively. Fatty acid composition in leaves of $A$. relicta is given in Table 1 and GC MS chromatogram is given in Figure 2.

21 fatty acids were found as a result of fatty acid analysis of Ajuga plant extract (Table 1). The major components in oil were palmitic acid (29.50\%), oleic acid (23.51\%), stearic acid $(9.13 \%)$, and linoleic acids $(7.18 \%)$. The researchers indicated that the need for saturated fats for energy, hormone production, cellular membranes and organs [22]. Total 50\% of the fatty acids of Ajuga are saturated fats. Some saturated fatty acids are also necessary for essential signalling and stabilization processes in the body. Saturated fatty acids that play an important role in these processes are known as palmitic acid, myristic acid and lauric acid [23]. A. relicta, which contains all three fatty acids, has palmitic acid predominantly. The most commonly found and produced fatty acids in animal fats are palmitic, stearic and oleic acids [24, 25]. Additionally, C16:0, C18:0, and cis-9 C18:1 are typically the most abundant FA found in commercial fat supplements commonly fed to dairy cows. The increase in the the level of palmitic and oleic acid gave better results in terms of energy quality [25]. These two fatty acids are also the major fatty acids in Ajuga oil. Essential fatty acids that animals cannot produce and must take from outside are linoleic acid (LA) (omega-6), arachidonic acid (AA) (omega-6), gamma linolenic acid (GLA) (omega-6), alpha linolenic acid (LNA) (omega-3), eicosapentaenoic acid (EPA) (omega-3) and docosahexaenoic acid. (DHA) (omega-3). According to our result, A. relicta contains all of these fatty acids in different proportions. 


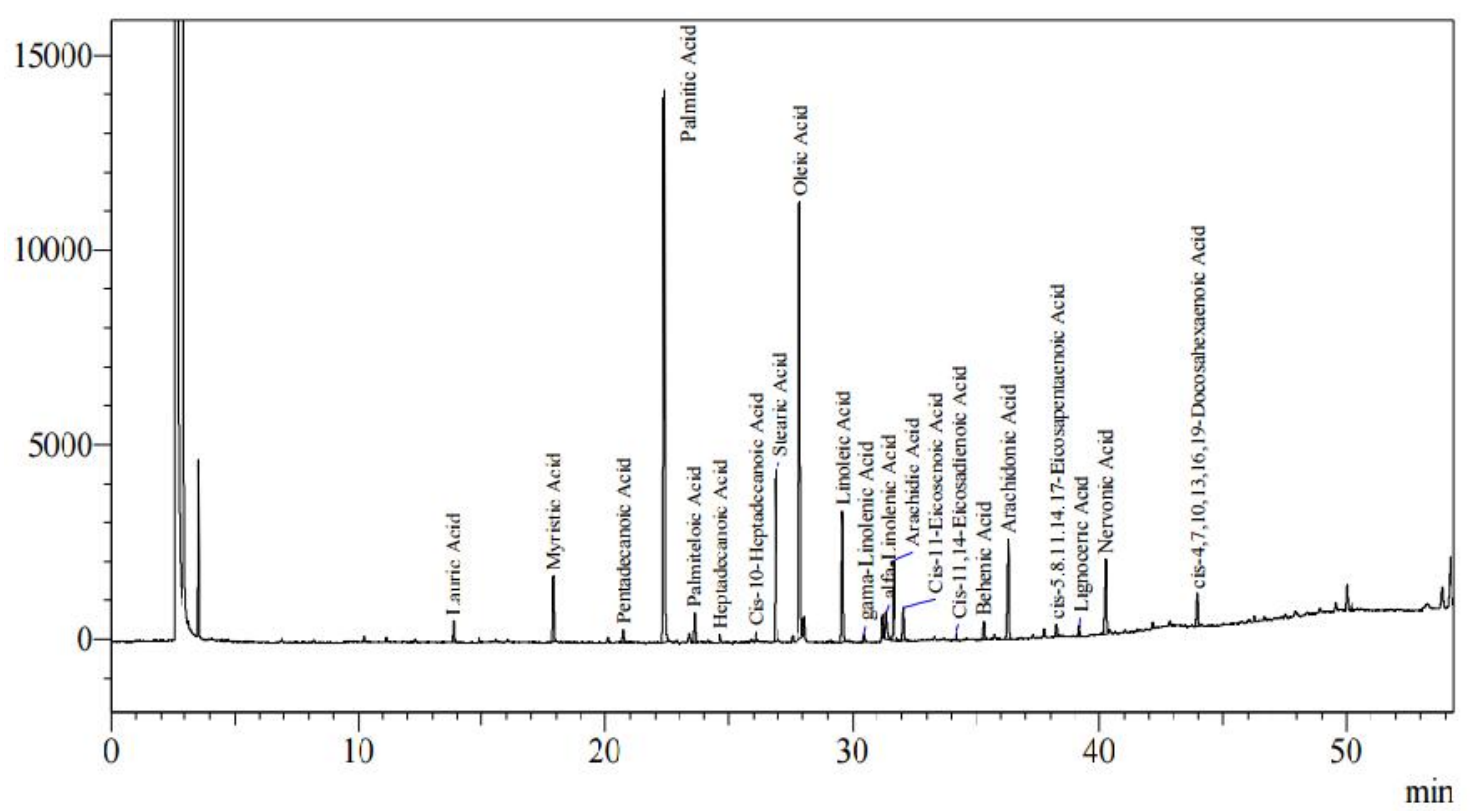

Figure 2. GC-MS chromatogram analysis of A. relicta extract

Table 1. Fatty acid compositions (\%) of the A. relicta.

\begin{tabular}{|c|c|c|c|}
\hline No & Carbon Number & Fatty Acids & Content $(\%)$ \\
\hline 1 & $\mathrm{C} 12: 0$ & Lauric Acid & $0.89 \pm 0.02$ \\
\hline 2 & $\mathrm{C} 14: 0$ & Myristic Acid & $3.27 \pm 0.01$ \\
\hline 3 & $\mathrm{C} 15: 0$ & Pentadecanoic Acid & $0.68 \pm 0.01$ \\
\hline 4 & C16:0 & Palmitic Acid & $29.50 \pm 0.03$ \\
\hline 5 & $\mathrm{C} 17: 0$ & Heptadecanoic Acid & $0.38 \pm 0.01$ \\
\hline 6 & C18:0 & Stearic Acid & $9.13 \pm 0.01$ \\
\hline 7 & C20:0 & Arachidic Acid & $4.73 \pm 0.01$ \\
\hline 8 & C21:0 & Behenic Acid & $0.92 \pm 0.00$ \\
\hline 9 & C24:0 & Lignoceric Acid & $0.50 \pm 0.00$ \\
\hline 10 & C16:1 & Palmitoleic Acid & $1.60 \pm 0.01$ \\
\hline 11 & $\mathrm{C} 17: 1$ & Cis-10-Heptadecanoic Acid & $0.48 \pm 0.00$ \\
\hline 12 & C18:1 & Oleic Acid & $23.51 \pm 0.01$ \\
\hline 13 & C20:1 & Cis-11-Eicosenoic Acid & $1.86 \pm 0.00$ \\
\hline 14 & $\mathrm{C} 24: 1$ & Nervonic Acid & $4.46 \pm 0.01$ \\
\hline 15 & C18:2 & Linoleic Acid & $7.18 \pm 0.01$ \\
\hline 16 & C20:2 & Cis-11,14-Eicosadienoic Acid & $0.38 \pm 0.00$ \\
\hline 17 & C18:3 & Gamma-Linolenic Acid & $0.49 \pm 0.00$ \\
\hline 18 & C18:3 & Alfa-Linolenic Acid & $1.90 \pm 0.00$ \\
\hline 19 & C20:4 & Arachidonic Acid & $5.66 \pm 0.01$ \\
\hline 20 & $\mathrm{C} 20: 5$ & $\begin{array}{l}\text { cis-5,8,11,14,17-Eicosapentaenoic } \\
\text { Acid }\end{array}$ & $0.69 \pm 0.00$ \\
\hline \multirow[t]{4}{*}{21} & $\mathrm{C} 22: 6$ & $\begin{array}{l}\text { cis- } 4,7,10,13,16,19- \\
\text { Docosahexaenoic Acid }\end{array}$ & $1.79 \pm 0.00$ \\
\hline & & SFA & 50.0 \\
\hline & & MUFA & 31.91 \\
\hline & & PUFA & 18.09 \\
\hline
\end{tabular}




\subsection{Total phenolic, flavonoid contents and antioxidant activity of $A$. relicta}

One of the most important points to be considered when working on the biological activities of plants is to elucidate the phytochemical composition. Herbal extracts consist of a mixture of very different phytochemicals. There is a strong relationship between phytochemical content and pharmacological potential of plants. One of the most studied and important phytochemical components of plants are phenolic compounds [26]. Various studies have shown that phenolic compounds are common in Ajuga species and may contribute to their antioxidant activity [2]. In this study, the total phenolic and flavonoid amounts of $A$. relicta extracts were determined in order to establish a relationship between the phenolic components and the biological activities of extracts. Phenolic, flavonoid and antioxidant activity properties were studied in Ajuga iva plant and methanolic extract showed the highest performance against hexane, chloroform and water extracts [27]. The researchers concluded that methanol is the most suitable solvent for the extraction of phenolic compounds and determination of antioxidant activity. Therefore, methanol was preferred as extraction solvent in this study. The results of antioxidant activity, total phenolic and flavonoid contents in A. relicta species are listed in Table 2.

Table 2. Total phenolic and flavonoid contents with antioxidant activity in the extracts of A. relicta

\begin{tabular}{cccc}
\hline $\begin{array}{c}\text { Total Phenolic } \\
\text { Content } \\
(\mathrm{mg} \mathrm{GAE} / \mathrm{g})\end{array}$ & $\begin{array}{c}\text { Total Flavonoid Content } \\
(\mathrm{mg} \mathrm{QE} / \mathrm{g})\end{array}$ & $\begin{array}{c}\mathrm{IC}_{50} \text { of DPPH\% } \\
(\mathrm{mg} \mathrm{dw} / \mathrm{ml})\end{array}$ & $\begin{array}{c}\text { FRAP } \\
(\mu \mathrm{g} \mathrm{AAE} / \mathrm{g})\end{array}$ \\
\hline $11.94 \pm 0.66$ & $2.28 \pm 0.64$ & $1.63 \pm 0.13$ & $43.53 \pm 0.48$ \\
\hline
\end{tabular}

The total phenolic content of A. relicta's methanolic extracts was $11.94 \mathrm{mg} \mathrm{GAE} / \mathrm{g} \mathrm{dw}$ and the total flavonoid content was $2.28 \mathrm{mg} \mathrm{QE} / \mathrm{g} \mathrm{dw}$. In the literature, the total phenolic content and $\mathrm{IC}_{50}$ value of the methanolic extract of $A$. relicta reported as $34.6 \mathrm{mg}$ GAE/g and 0.205 $\mathrm{mg} / \mathrm{ml}$, respectively [12]. Although plants were collected from the same location and in the same year, we have obtained a significant decrease compared to Sönmez and Köse [12] in terms of phenolic content and IC50 value. The decrease may be due to seasonal differences and vegetative maturity. Collection time of the plant in their study [12] was at the beginning of June while our collection time was at the end of July. Since the June is flowering stage, while the July is seeding stage of plant. The total phenolic content of A. relicta was found to be lower than the methanolic extract of A. laxmannii (56.76 mg GAE/g dw) [2]. The total phenolic content in flower portions of $A$. reptans and aerial fragments of A. chamaecistus subsp. scoparia were $20.86 \mathrm{mg} \mathrm{GAE} / \mathrm{g} \mathrm{dw}$ and $20.32 \mathrm{mg} \mathrm{GAE} / \mathrm{g} \mathrm{dw}$, respectively [28, 29]. The total phenolic content of $A$. relicta was found be higher than A. reptans and A. chamaecistus subsp. scoparia. In previous studies, Toiu et al. [28] found a TFC value of $12.38 \pm 0.22 \mathrm{mg} \mathrm{RE} / \mathrm{g} \mathrm{dw}$ for a methanol extract of $A$. reptans flowers. The flavonoid content of $A$. laxmannii was $36.14 \pm 0.53$ mg RE/g dw; water, ethyl acetate, methanol and acetone extract of A. chamaepitys L. Schreb TFC value $9.32 \pm 0.33,91.76 \pm 0.81,63.87 \pm 0.66$, and $61.77 \pm 0.51 \mathrm{mg} \mathrm{RE} / \mathrm{g} \mathrm{dw}$, respectively $[2,30]$.

Numerous test systems have been developed to determine the antioxidant activity of plant extracts. Each test system evaluates the antioxidant activity of the test material from a different perspective [31]. The best way to measure the antioxidant activity of a plant extract is to combine two or more complementary test systems. In this study, antioxidant activity of $A$. relicta extracts was evaluated using radical scavenging and reducing power analysis. DPPH analysis was used to determine the radical scavenging activity of the extract and FRAP analysis was used to determine the activity of reducing power (Table 2). According to the data presented in the table, the clearance activity of the extract on DPPH radicals was calculated as $\mathrm{IC}_{50}$ value 
and was determined to be $1.63 \mathrm{mg} \mathrm{dw} / \mathrm{ml}$. In FRAP analysis, the FRAP activity of Ajuga extract was obtained as $43.53 \mu \mathrm{g}$ AAE/g.

Phenolic compounds are considered to be functional bioactive compounds. According to the results of many studies, these compounds are also the main compounds that contribute to the antioxidant activities of plants [32]. The high antioxidant activity of $A$. relicta extracts can be explained by the high phenolic compound contents.

\subsection{Antimicrobial activity of $A$. relicta}

Most of the therapeutic agents used in disease treatment are obtained from plant sources. The number of plant species that are under investigation to reveal their therapeutic potential, have been increasing day by day [26]. Despite all these efforts, there are many plant species that have not yet been investigated for their biological and/or pharmacological potential. $A$. relicta, which is the subject of this study, is one of these plants. According to the results of our literature review, no data is available in the literature concerning the antimicrobial activity of A. relicta.

The antimicrobial effect of the methanolic extract of $A$. relicta was examined against seven bacteria and four yeasts. The results showed that the methanolic extracts of $A$. relicta have significant inhibitory activity against all tested bacteria except $E$. cloaca. The inhibition zones of the methanolic extract of $A$. relicta, which were obtained against all test bacteria, were in the range of 10-12 $\mathrm{mm}$ and $9 \mathrm{~mm}$ for tested fungi (Table 3). When the MIC values were examined, it was seen that $A$. relicta extract had higher inhibitory effect on $E$. coli than other bacteria. The highest inhibitory activity was determined against $E$. coli. On the other hand, the weakest inhibitory activity was determined against E. faecalis, . pneumonia and S. lutea.

Table 3. The antimicrobial activity of $A$. relicta against test microorganisms

\begin{tabular}{|c|c|c|c|}
\hline Test bacteria & Inhibition Zone (mm) & Gentamicin $(\mathrm{mm})$ & MIC $(\mathrm{mg} / \mathrm{ml})$ \\
\hline Bacillus subtilis ATCC6633 & 10 & 21 & 12.5 \\
\hline E. Cloaca* & - & 16 & NT \\
\hline Enterococcus faecalis* & 12 & 26 & 25 \\
\hline Escherichia coli 309628 & 12 & 24 & 6.25 \\
\hline Klebsiella pneumonia* & 11 & 28 & 25 \\
\hline Staphylococcus aureus* & 10 & 25 & 12.5 \\
\hline Sarcina lutea ATCC 9341NA & 12 & 28 & 25 \\
\hline Test fungus & & Nystatine (mm) & \\
\hline Candida albicans* & 9 & 18 & 1.562 \\
\hline Candida glabrata* & - & 18 & NT \\
\hline Candida parapsilosis* & 9 & 18 & 12.5 \\
\hline Saccharomyces cerevisia & - & 24 & NT \\
\hline
\end{tabular}

${ }^{\text {*}}$ Clinical isolate, NT: Not tested, -: No inhibition zone

Among the 4 yeast strains, $C$. parapsilosis and $C$. albicans was inhibited by A. relicta extracts, while Candida glabrata and Saccharomyces cerevisiae were not affected. It could be an important property having an inhibitory and non-inhibitory activity against pathogenic and non-pathogenic strains, respectively, for food and pharmaceuticals. In terms of extraction method, although various the most promising results were obtained with the activity of $A$. relicta against $C$. albicans (MIC: $1.562 \mathrm{mg} / \mathrm{ml}$ ). Around the world, so many plants were screened by many researchers with different methods against different microorganisms. Here in this study, the methanolic extract of $A$. relicta obtained was tested against common 
microorganisms. As a result, these extracts seem to be reasonably effective against test organisms including clinical isolates. Plant phenolic compounds are known to be responsible for a variety of biological properties, including antimicrobial properties [27]. Therefore, it is thought that the antimicrobial activity of A. relicta extracts is related to the phenolic and flavonoid compounds of the plant.

\section{CONCLUSION}

In this study, phenolic and flavonoid content, antioxidant, antimicrobial activity and fatty acids of $A$. relicta, which is endemic and a relict species were evaluated. Other species belonging to the genus Ajuga spreads in 5 continents around the world and used for medical purposes among the population. A. relicta is a forgotten plant because of its naturally spread in a very narrow environment and also narrowing with various pressures. With this study, $A$. relicta was found to have high bioactive content and antimicrobial activity, as well as other members of the genus. It has been found that plant extracts show profile rich in constant fatty acids and show a profile similar to olive oil (palmitic-oleic-linoleic), which is well known for its health benefits in terms of major fatty acids.

\section{Orcid}

Nazan Çömlekcioğlu (iD) https://orcid.org/0000-0001-7729-5271

Yusuf Ziya Kocabaş (i) https://orcid.org/0000-0003-2831-8910

Ashabil Aygan (iD https://orcid.org/0000-0003-4936-9872

\section{REFERENCES}

[1] Atanasov, A.G., Waltenberger, B., Pferschy-Wenzig, E.M., Linder, T., Wawrosch, C., Uhrin, P., et al. (2015). Discovery and resupply of pharmacologically active plant-derived natural products: a review. Biotechnol. Adv., 33(8), 1582-1614.

[2] Toiu, A., Mocan, A., Vlase, L., Pârvu, A.E., Vodnar, DC, Gheldiu, AM, et al. (2018). Phytochemical Composition, Antioxidant, Antimicrobial and in Vivo Anti-inflammatory Activity of Traditionally Used Romanian Ajuga laxmannii (Murray) Benth.("Nobleman's Beard"-Barba Împăratului). Front. Pharmacol., 9, 7.

[3] Tzima, K., Brunton, N. \& Rai, D. (2018). Qualitative and Quantitative Analysis of Polyphenols in Lamiaceae Plants-A Review. Plants, 7(2), 25.

[4] Davis, P.H. (1982). Flora of Turkey and the East Aegean Islands, Vol. 10, p. 43. University Press, Edinburgh.

[5] Sönmez, E. \& Köse, Y.B. (2008). Morpho-anatomical investigations on Ajuga postii Briq and Ajuga relicta PH Davis. Biological Diversity and Conservation, 10(1),39-49.

[6] Dönmez, M., Kargığlu, M. \& Temel, M. (2011). Stachys palustris L.'in morfolojik, anatomik ve ekolojik özellikleri. AKÜ Fen Bilimleri Dergisi, 11, 1-9.

[7] El Hilaly, J., Israili, Z.H. \& Lyoussi, B. (2004). Acute and chronic toxicological studies of Ajuga iva in experimental animals. J. Ethnopharmacol., 91(1), 43-50.

[8] Baytop, T. (1999). Therapy with medicinal plants in Turkey (past and present). Publication of the Istanbul University. p. 312.

[9] Doygun, H., Kısakürek, S., Erdoğan, N. \& Hatipoğlu, I.H. Kahramanmaraş-Ahir Dağ1 Bitki Örtüsü Değişiminin Uzaktan Algılama Yöntemi ile ncelenmesi, II. Ulusal Akdeniz Orman ve Çevre Sempozyumu, Isparta, Turkey, 22-24 October, 2014.

[10] Varol, O., lçim, A. \& Tatli, A. (1998). New observation on two poorly known Turkish species. Thaiszia Kosice., 8, 53-56. 
[11] Kokdil, G., Topcu, G., Gorenc, A.C. \& Voelterd, W. (2002). Steroids and terpenoids from Ajuga relicta. Z. Naturforsch. B., 57(8), 957-960.

[12] Sönmez, E. \& Köse, Y.B. (2017). The Total Phenolic Contents and Antioxidant Activities of Endemic Species Ajuga postii Briq. and Ajuga relicta PH Davis (Lamiaceae) from Turkey. Indian J. Pharm. Educ., 51(4), 700-705.

[13] Albayrak, S., Aksoy, A., Sagdic, O. \& Budak, U. (2010). Phenolic compounds and antioxidant and antimicrobial properties of Helichrysum species collected from eastern Anatolia, Turkey. Turk. J. Biol., 34(4), 463-473.

[14]UNIEN 14775, (2010). Solid biofuels, determining the ash content.

[15] AOAC, (1990). Official method of analysis. Association of official analytical chemists. $15^{\text {th }}$. edition, pp.66-88

[16] Blainski, A., Lopes, G.C. \& De Mello, J.C.P. (2013) Application and analysis of the Folin Ciocalteu method for the determination of the total phenolic content from Limonium brasiliense L. Molecules, 18(6), 6852-6865.

[17]Chang, C.C., Yang, M.H., Wen, H.M. \& Chern, J.C. (2002). Estimation of total flavonoid content in propolis by two complementary colorimetric methods. J. Food Drug Anal., 10(3), 178-182.

[18]Brand-Williams, W., Cuvelier, M.E. \& Berset, C.L.W.T. (1995). Use of a free radical method to evaluate antioxidant activity. LWT - Food Sci Technol., 28(1), 25-30.

[19]Benzie, I.F. \& Strain, J.J. (1996). The ferric reducing ability of plasma (FRAP) as a measure of "antioxidant power": the FRAP assay. Anal. Biochem., 239(1), 70-76.

[20]Collins, C.H., Lyne, P.M. \& Grange, J.M. (1989). Collins and Lyne's Microbiological Methods, Sixth Edition, Butterworths Co. Ltd. London.

[21] Siciliano, C., Belsito, E., De Marco, R., Di Gioia, M.L., Leggio, A. \& Liguori, A. (2013). Quantitative determination of fatty acid chain composition in pork meat products by high resolution 1 H NMR spectroscopy. Food Chem., 136(2), 546-554.

[22] Van Immerseel, F., Boyen, F., Gantois, I., Timbermont, L., Bohez, L., Pasmans, F., et al. (2005). Supplementation of coated butyric acid in the feed reduces colonization and shedding of Salmonella in poultry. Poultry Sci., 84(12), 1851-1856.

[23] Mohanty, B.P., Bhattacharjee, S., Paria, P., Mahanty, A. \& Sharma, A.P. (2013). Lipid biomarkers of lens aging. Appl. Biochem. Biotech., 169(1), 192-200.

[24] Gunstone, F.D., Harwood, J.L. \& Dijkstra, A.J. (2007). "The Lipid Handbook with CdRom. 3rd ed. Boca Raton: CRC Press, ISBN 0849396883 | ISBN 978-0849396885.

[25]De Souza, J., Preseault, C.L. \& Lock, A.L. (2018). Altering the ratio of dietary palmitic, stearic, and oleic acids in diets with or without whole cottonseed affects nutrient digestibility, energy partitioning, and production responses of dairy cows. J. Dairy Sci., 101(1), 172-185.

[26] Sarikurkcu, C., Kirkan, B., Ozer, M.S., Ceylan, O., Atilgan, N., Cengiz, M. \& Tepe, B. (2018). Chemical characterization and biological activity of Onosma gigantea extracts. Ind. Crops Prod., 115, 323-329.

[27] Makni, M., Haddar, A., Kriaa, W. \& Zeghal, N. (2013). Antioxidant, free radical scavenging, and antimicrobial activities of Ajuga iva leaf extracts. Int. J. Food Prop., 16(4), 756-765. 
[28] Toiu, A., Vlase, L., Gheldiu, A.M., Vodnar, D. \& Oniga, I. (2017). Evaluation of the antioxidant and antibacterial potential of bioactive compounds from Ajuga reptans extracts. Farmacia, 65, 351-355.

[29] Movahhedin, N., Zengin, G., Bahadori, M.B., Sarikurkcu, C., Bahadori, S. \& Dinparast, L. (2016). Ajuga chamaecistus subsp. scoparia (Boiss.) Rech. f.: A new source of phytochemicals for antidiabetic, skin-care, and neuroprotective uses. Ind. Crops Prod., 94, 89-96.

[30] Jakovljević, D.Z., Vasić, S.M., Stanković, M.S., Čomić, L.R. \& Topuzović, M.D. (2015). Secondary metabolite content and in vitro biological effects of Ajuga chamaepitys (L.) Schreb. subsp. chamaepitys. Arc. Biol. Sci., 67(4), 1195-1202.

[31] Kocak, M.S., Uren, M.C., Calapoglu, M., Tepe, A.S., Mocan, A., Rengasamy, K.R.R. \& Sarikurkcu, C. (2017). Phenolic profile, antioxidant and enzyme inhibitory activities of Stachys annua subsp. annua var. annua. S. Afr. J. Bot., 113, 128-132.

[32] Shahidi, F. \& Ambigaipalan, P. (2015). Phenolics and polyphenolics in foods, beverages and spices: antioxidant activity and health effects - a review. J. Funct. Foods., 18, 820-897. 